\title{
Effects of the Exchange Rate on Output and Price Level: Evidence from the Pakistani Economy
}

\author{
Munir A. S. Choudhary ${ }^{*}$ and Muhammad Aslam Chaudhry
}

\begin{abstract}
The question of whether devaluation of the currency affects output positively or negatively has received considerable attention both from academic and empirical researchers. A number of empirical studies have supported the contractionary devaluation hypothesis using pooled time series data from a large number of heterogeneous countries. Since the effects of devaluation on output and the price level may not be uniform across all developing countries, the empirical results can not be generalized for all countries. In addition, almost none of the empirical studies used to test the contractionary devaluation hypothesis separate the effects of devaluation from import prices. Thus, a country specific study is needed that separate the effects of devaluation from the import price effects. This paper uses a VEC model to analyze the effects of the exchange rate on output and the price level in Pakistan for the period 1975-2005. Our analysis shows that devaluation has a positive effect on output but a negative effect on the price level. Thus, the evidence presented in this paper does not support the contractionary devaluation hypothesis for the Pakistani economy.
\end{abstract}

\section{Introduction}

There are numerous channels through which the effects of currency fluctuations are transmitted onto the domestic price level and output. Under a fixed exchange rate system, official changes in the value of a country's currency relative to other currencies are called devaluations and revaluations. Whereas under a flexible exchange rate system, market forcegenerated changes in the value of the country's currency are known as depreciations and appreciations. In this paper, the terms depreciation and devaluation are used interchangeably.

\footnotetext{
* Foreign Professor, Department of Economics, University of the Punjab

** Professor and Chairman, Department of Economics, University of the Punjab
} 
According to the conventional textbook model, depreciation of the domestic currency makes the country's exports relatively cheaper for foreigners and makes foreign goods relatively more expensive for domestic consumers. This helps to increase the countries exports and switches demand towards domestically produced goods, and therefore shifts the aggregate demand curve to the right (Dornbusch 1988). In the short-run, when the economy is operating at a positively sloped aggregate supply curve, a depreciation of the domestic currency will cause both output and the price level to increase. However, in the long-run when the economy is operating on the vertical portion of the aggregate supply curve, the price level will increase proportionately with no effect on the output level. Under the assumption that devaluations are expansionary, Pakistan like many other developing countries, resorted to large devaluations in the hope of reaping economic benefits ${ }^{1}$. During the fixed exchange rate period (1971-81), the Pak rupee was devalued from 4.79 to 9.90 per US dollar. During the managed float period (1982-1999) the rupee was devalued from 9.90 to 51.78 per US dollar. During the flexible exchange rate period (2000-2006) the rupee has depreciated from 51.78 to 60.6 per US dollar. The nominal effective exchange rate, which measures the value of the Pak rupee against a weighted average of foreign currencies, shows a similar trend. As shown in figure 1 , the nominal effective exchange rate $(2000=1000)$ has continually declined since 1982 .

Figure 1

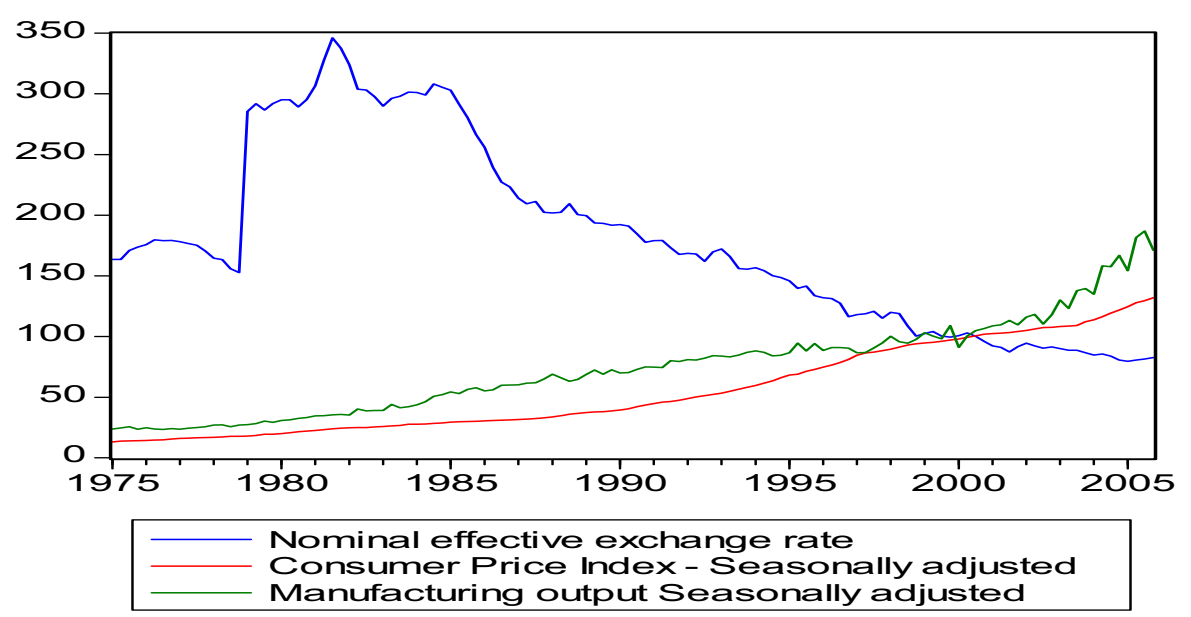

As mentioned above, the conventional textbook view predicts that the price level and output are negatively related to the value of the domestic currency. To illustrate this negative correlation, the consumer 
price index and manufacturing output index are plotted in figure 1 and their correlation coefficients are given below in Table-1.

Table-1: Correlation Coefficients between Exchange Rate - Price Level and Output

\begin{tabular}{lcc}
\hline \multicolumn{1}{c}{ Variables } & Period & Correlation Coefficient \\
\hline NEER-CPI & $1975: 1-2005: 4$ & -0.80 \\
NEER-Output & $1975: 1-2005: 4$ & -0.75 \\
\hline
\end{tabular}

Note: CPI denotes consumer price index seasonally adjusted, Output is manufacturing production, NEER is nominal effective exchange rate. The correlation coefficients are all different from zero at the 5\% significance level.

As shown in Table-1, the correlation between the exchange rate and price level is -0.80 ; between exchange rate and output, it is -0.75 . These negative and statistically significant coefficients indicate that devaluations have an expansionary effect on the Pakistan economy as predicted by the conventional view. Yet, one should not read too much from the correlation analysis. This strong negative correlation between the exchange rate and other variables as shown in figure 1 and in Table- 1 may be a spurious correlation. Furthermore, the bivariate results do not provide information regarding the channels through which the exchange rate might affect output.

However, this textbook view is not uniformly supported either by prior theoretical research or actual historical experience. In recent years, a growing literature argues for contractionary devaluation by concentrating on aggregate demand and aggregate supply models. The most important channels through which devaluation may create negative effects on aggregate demand and thus contraction in output are:

Income Redistribution Channel: Devaluation can generate a redistribution of a given level of real income from wages to profits (DiazAlejandro, 1963; Cooper, 1971a; Knight, 1976; and Krugman and Taylor, 1978). The effect of income redistribution is based on the argument that there are different consumer groups in a society. These groups can be broadly divided into two categories: wage earners and profit earners. The marginal propensity to save is assumed to be higher for profit recipients than for wage earners. Devaluation leads to higher prices and profits in export and import competing industries while sticky nominal wages reduce 
real wages. Since the marginal propensity to save is higher from profits than from wages, the economy's average propensity to save will rise and this will tend to be demand contractionary.

Interest Rate Channel: Devaluation leads to higher interest rates (Bruno, 1979, and Van Wijnbergen, 1986). An increase in the domestic price level as a result of devaluation will increase the demand for nominal money (which is same thing as a decrease in real money balances) and thus the nominal interest rates. The increase in the interest rate will tend to reduce investment and consumption expenditure through traditional mechanisms.

Investment Channel: A decline in new investment (Branson, 1986; Buffie, 1986 and Van Wijnbergen, 1986). Since a substantial portion of any new investment in developing countries consists of imported capital goods, depreciation raises the cost of imported capital and reduces its imports. This discourages new investment and exerts contractionary pressure on aggregate demand.

External Debt Channel: Devaluation results in a higher cost of large external debts (Cooper, 1971b; Gylfason and Risager, 1984 and Van Wijnbergen, 1986). In developing countries, most external debt is denominated in dollars or in another strong foreign currency. If a country having large debt devalues its currency, then both residents and the government need more domestic currency to pay for the same amount of foreign debt. This reduces the net wealth and therefore aggregate expenditure. Another argument is that in developing countries, a very large proportion of the external debt is owed by the public sector. Devaluation increases the domestic currency costs of serving debt. The government can finance increased debt service payments by reducing its expenditures, increased taxation or domestic borrowing. All these modes of financing have contrationary effects on aggregate demand.

Real Balance Channel: Devaluation causes a decrease in real balances (Bruno, 1979; Gylfason and Radetzki, 1991). Devaluation increases the prices of traded goods and that leads to an increase in the general price level. An increase in the general price level decreases real cash balances and real wealth which tends to decrease personal spending.

Redistribution of income from the private sector to the government sector (Krugman and Taylor, 1978). Since the demand for imported goods is inelastic, devaluation increases the domestic currency value of imports while their volume remains unchanged. This increased domestic currency 
value of trade causes ad valorem trade taxes (tariff revenue) to rise. As a result, there will be a redistribution of income from the private sector to the government. An increase in government's tax revenue means less is left for the private sector. In the short-run, the marginal propensity to save for the government sector is close to one, thus government spending remains unchanged and aggregate demand decreases due to decrease in private consumption.

Similarly, a number of supply-side channels are identified through which devaluation can be contractionary. Some of these supply-side channels are discussed below:

Higher cost of imported inputs channel (Krugman and Taylor, 1978; Bruno, 1979; Gylfason and Schmid, 1983; Hanson, 1983; Gylfason and Risager, 1984; Solimano, 1986; Edwards, 1986; VanWijnbergen, 1986 and Gylfason and Radetzki, 1991). In many developing countries imports consist of predominately noncompetitive intermediate inputs or capital goods. Devaluation increases the domestic currency cost of imported inputs and reduces the volume of imported inputs. A reduction in imports implies insufficient inputs necessary for production. Thus, because of the lack of inputs and higher cost relative to the prices of their domestic final products, firms tend to produce less, which leads to a reduction in aggregate supply.

Higher wage costs channel (Krugman and Taylor, 1978; Bruno, 1979; Gylfason and Schmid, 1983; Hanson, 1983; Gylfason and Risager, 1984; Solimano, 1986; Edwards, 1986; VanWijnbergen, 1986 and Gylfason and Radetzki, 1991). Increased prices of traded goods caused by devaluation ultimately result in a general price level increase. As real wages decrease, the workers will demand higher nominal wages to protect their purchasing power. If wages are flexible or there exists a wage indexation mechanism, the nominal wages will adjust proportionately to the general price level. Such increases in wages increase the cost of production and could produce adverse supply effects.

Higher cost of working capital channel (VanWijnbergen, 1986). Working capital is basically short-term funds needed by the firms to carry out their daily business. Devaluation increases the price level hence the real money supply decreases. This leads to a decline in the real volume of credit. If the credit supply decreases relative to demand, interest rates tend to climb, making working capital more costly. This will push up the cost of production, hence adversely affecting the supply of output. 
Foreign exporters as price taker in the domestic economy (knitter, 1989). Foreign exporters face an upward sloping marginal cost curve and a horizontal marginal revenue curve. The quantity produced and supplied by the foreign producer is determined by the intersection of marginal revenue and marginal cost curves. Now suppose that the value of the domestic currency decreases. The price received by a foreign producer in terms of his own currency will be lower. In other words the marginal revenue curve faced by foreign producer will shift down and it will intersect the marginal cost curve at a lower level of output. At a given price level in the domestic economy, the output supplied by the foreign producer will decrease and this will result in a leftward shift of aggregate supply curve in the domestic economy.

In spite of the renewed theoretical interest in the possible contractionary effects of devaluations, the empirical evidence is mix at best. A review of existing studies indicates that four major empirical approaches have been utilized to investigate the effects of devaluation on output: The control group approach, the before and after approach, the macrosimulation approach and the econometric approach.

The control group approach (Donovan, 1982; Gylfason, 1987; Kamin, 1988; Edwards, 1989 and Khan, 1990). This approach aims at separating the effect of devaluation from other factors on output. Donovan (1982) studied 78 IMF-supported devaluations. He concluded that economic growth fell by more than the average decline experienced by non-oil developing countries in one-year comparisons but by less in three years comparisons. Gylfason (1987) studied 32 IMF-supported programs during 1977-1979 and found that differences in output growth between countries with IMF programs and non-program countries were not statistically significant. Kamin (1988) analyzed 107 devaluations between 1953 and 1983 and concluded that devaluation has either an expansionary or no effect. Contraction takes place prior to devaluation and continues after devaluation. Edwards (1989) studied 18 devaluations in Latin America and concluded that declines in output growth were not due to devaluation, but due instead to the accompanying restrictions that have accompanied devaluations. Khan (1990) studied the effects of IMF supported programs in a group of 69 developing countries over 1973-1988. He found that devaluations were contractionary but this result was not statistically significant.

The before and after approach (Diaz-Alejendro, 1965; Cooper, 1971a; Killick, Malik, and Manue1, 1992). This approach studies changes in country performance at the time of devaluation. Diaz-Alejendro (1965) examined the experience of Argentina over the period 1955-1961. He 
concluded that the 1959 devaluation of the peso was contractionary as it shifted the income distribution toward high savers, which depressed consumption. Cooper (1971a) analyzed 24 devaluations that took place between 1953 and 1966 in less developed countries. After looking at the behavior of the major components of aggregate demand, he concluded that devaluations had a contractionary effect on output. Killick, Malik, and Manuel (1992) examined the results of 266 IMF-supported programs implemented during the 1980s. Many of them incorporated nominal devaluation as a key policy measure. They concluded that these programs had no noticeable effect on output growth in short term; however, over the longer term growth rates were improved.

The macro-simulation approach (Gylfason and Schmid, 1983; Gylfason and Risager, 1984; Solimano, 1986; and Roca and Priale, 1987). This approach uses simulation models to analyze the impact of exchange rate changes on output. Gylfason and Schmidt (1983) constructed a small macro model of an open economy. They found that a devaluation causes expansionary effects through aggregate demand and contractionary effects through aggregate supply. Their study concluded that devaluation was expansionary in 8 out of 10 countries. Gylfason and Risager (1984) studied the effects of devaluation for 8 developing and 7 developed countries. They concluded that devaluation was expansionary in developed countries and contractionary in developing countries. Solimano (1986) constructed a macroeconomic model for Chile and concluded that devaluation was contractionary in the short to medium run. Roca and Priale (1987) constructed a macroeconomic model for the Peruvian economy and concluded that devaluations were contractionary.

The econometric approach (Sheehey, 1986; Edwards, 1989; Morley, 1992; Upadhyaya, 1999 and Bahmani-Oskooee and Miteza, 2006). This approach applies econometric methods to time series data to investigate the effect of devaluations on output. Sheehey (1986) used cross section data from 16 Latin American countries and concluded that devaluations had a contractionary effect on output. Morley (1992) also used cross section data from 28 developing countries and found support for the contractionary devaluation hypothesis. Edwards (1989) used panel data regressions for 12 developing countries and found that devaluations were contractionary in the short-run. Upadhyaya (1999) applied cointegration and error correction modeling techniques to data from 6 Asian countries and concluded that devaluations were contractionary for Pakistan and Thailand but neutral for India, Sri Lanka, Malaysia and Philippines in the long-run. Bahmani-Oskooee and Miteza (2006) applied panel unit root and panel cointegration techniques to annual data from 42 
countries and concluded that in the long-run devaluations were contrationary in non-OECD countries.

In addition to cross-section econometric studies, a number of econometric studies have also used time series data to investigate the contractionary devaluation hypothesis. Bahmani-Oskooee and Rhee (1997) using Korean quarterly data over the period 1971-1974 applied Johansen's cointegration and error-correction technique. Their error-correction model confirmed that there exists a long-run relationship between output, money and the real exchange rate variables. They concluded that real depreciations were expansionary in the long-run and the most important expansionary impact of real depreciations appeared with a lag of three quarters. Domaç (1997) examined the contractionary devaluation hypothesis in Turkey for the period $1960-1990$ by distinguishing the growth effects of anticipated and unanticipated devaluations. He found that unanticipated devaluations had a positive impact on real economic activity, while anticipated devaluations did not exert any significant effect on output. Bahmani-Oskooee (1998) used quarterly data from 23 LDCs countries over the 1973-1988 periods to investigate the long-run effects of devaluation. He used ADF tests to check whether output and effective exchange rate were cointegrated. He concluded that devaluations were neutral with respect to output in the long-run for most LDCs. However, when Bahmani-Oskooee et al. (2002) applied Johansen's cointegration technique, they found that devaluations were expansionary in the Philippines and Thailand but contractionary in Indonesia and Malaysia. De Silva and Zhu, (2004) considered the case of Sri Lanka and applied the VAR technique. Using quarterly data over the period 1976-1998, they concluded that devaluation improved the trade balance but had a contractionary impact on the Sri Lankan economy.

The studies reviewed above show that results concerning the effects of devaluation on output are quite mixed. This leaves room for new empirical research. The econometric approach has desirable properties because it enables the researcher not only to capture the effects of devaluation but also the effects of other factors on output. Almost all econometric studies that support the contractionary devaluation hypothesis use pooled time series data from a large number of heterogeneous countries. Since the effects of devaluation on output and price level may not be uniform across all developing countries, an empirical study of the individual experience of Pakistan can be a valuable addition to the literature. 
The objective of this paper is to examine the effects of exchange rate changes on the price level and real output using data on Pakistan. In section II, the methodology used in this paper is discussed. Section III describes the data, estimation and evaluation of empirical results. Section IV gives the concluding remarks.

\section{Methodology}

The main objective of this paper is to investigate the effects of exchange rate fluctuations on inflation and output growth. As is well known, under a fixed exchange rate system monetary authorities maintain the exchange rate at a predetermined level and allow the macroeconomic variables such as the price level and output to fluctuate. Thus, under a fixed exchange rate system, the exchange rate is treated as an exogenous variable and causality runs from exchange rate to other macroeconomic variables. However, in a flexible exchange rate system, the exchange rate like many other macroeconomic variables, is determined by the market conditions. Thus, under a flexible exchange rate system, the exchange rate, price level and output are expected to affect each other. Since this study covers the flexible exchange rate period, a vector autoregression (VAR) methodology is appropriate because it allows interaction among macroeconomic variables. The basic version of VAR is regarded as an unrestricted reduced form of a structural model. One advantage of this approach is that the specification is purely determined on the information contained in the available data and does not need any additional nontestable a priori restrictions.

We assume that the economy is described by a system of six equations: an import price level equation, an exchange rate equation, an interest rate equation, a money supply equation, a price level equation and an output level equation. We set up the following VAR model with the vector of six endogenous variables ${ }^{2}$ :

$$
\mathrm{Z}_{\mathrm{t}}=\left(F_{t}, \mathrm{M}_{\mathrm{t}}, \mathrm{R}_{\mathrm{t}}, \mathrm{E}_{\mathrm{t}}, \mathrm{P}_{\mathrm{t}}, \mathrm{Y}_{\mathrm{t}}\right)
$$

where

$\mathrm{F}=$ Unit value of imports. The unit value of imports is included in the VAR to capture the effects of foreign supply shocks on domestic macroeconomic variables. To separate the effects of the unit value of imports from the foreign exchange rate effects, the unit value of imports is measured in U.S. dollars. 
$\mathrm{M}=\mathrm{M} 2$ definition of money supply.

$\mathrm{R}=$ Short-term interest rate measured by call money rates.

$\mathrm{E}=$ Nominal effective exchange rate. Although many studies have used bilateral exchange rates in their analysis, Mohsen Bahmani-Oskooee and Iler Mteza (2006) have pointed out that a country's currency could depreciate against one country and appreciate against an other country and thus the effective exchange rate is the appropriate concept to capture variation in the overall value of the currency.

$\mathrm{P}=$ Domestic price level measured by consumer price index.

$\mathrm{Y}=$ Real output. Since quarterly data on real output is not available for Pakistani economy, manufacturing output is used as a proxy for real output.

We assume that the dynamic behavior of $\mathrm{Z}_{\mathrm{t}}$ is governed by the following structural model:

$$
\mathrm{B}(\mathrm{L}) \Delta \mathrm{Z}_{\mathrm{t}}=\mu_{\mathrm{t}}
$$

where $\mathrm{B}(\mathrm{L})$ is a $\mathrm{k}^{\text {th }}$ order matrix polynomial in the lag operator $\mathrm{L}$ such that $\mathrm{B}(\mathrm{L})=\mathrm{B}_{0}-B_{1} L-B_{2} L^{2}-\ldots \ldots . .-B_{\mathrm{k}} L^{\mathrm{k}} . \mathrm{B}_{0}$ is a non-singular matrix normalized to have one on the diagonal and summarizes the contemporaneous relationship between the variables contained in the vector $Z_{t} \cdot \mu_{t}$ is a vector of structural disturbances and is serially uncorrelated. $\mathrm{E}\left(\mu_{\mathrm{t}} \mu_{\mathrm{t}}\right)=\Sigma_{\mu}$ and it is a diagonal matrix while $\mathrm{E}$ represents the expectations sign. $\Sigma_{\mu}$ is a diagonal matrix where diagonal elements are the variance of the structural disturbances and off-diagonal elements are zero (structural error terms are assumed to be mutually uncorrelated).

The empirical estimation of (2) is achieved by applying the Wold representation theorem and inverting it to derive the reduced form VAR which is given below:

$$
\mathrm{A}(\mathrm{L}) \Delta \mathrm{Z}_{\mathrm{t}}=\varepsilon_{\mathrm{t}}
$$


where $\mathrm{A}(\mathrm{L})$ is matrix polynomial in the lag operator $\mathrm{L}, \varepsilon_{t}$ is a vector of serially uncorrelated reduced form disturbances and $\mathrm{E}\left(\varepsilon_{\mathrm{t}} \varepsilon_{t}^{\prime}\right)=\Sigma_{\varepsilon}$. The components of equation (3) to equation (2) are related as given below:

$$
\begin{gathered}
\mathrm{A}(\mathrm{L})=\mathrm{B}_{0}^{-1} B(L)=\mathrm{I}-\mathrm{A}_{1} L-A_{2} L^{2}-\ldots \ldots \ldots \ldots-A_{k} L^{k} \\
\varepsilon_{t}=\mathrm{B}_{0}^{-1} \mu_{t}
\end{gathered}
$$

In order to recover the structural parameters of the VAR model specified by equation (2) from the estimated reduced form coefficients of equation (3), the model must be either exactly identified or over identified. Exact identification requires that number of parameters in $\mathrm{B}_{0}$ and $\Sigma_{\mu}$ are equal to number of parameters in the covariance matrix $\Sigma_{t}$. Using equations (4) and (5), the parameters of structural equation (2) and of reduced form equation (2) are related as below:

$$
\begin{aligned}
\mathrm{A}(\mathrm{L}) & =\mathrm{I}-\mathrm{B}_{0}^{-1}\left[\mathrm{~B}_{1} L-B_{2} L^{2}-\ldots \ldots \ldots . B_{k} L^{k}\right] \\
\sum_{\varepsilon} & =\mathrm{B}_{0}^{-1} \sum_{\mu} \mathrm{B}_{0}^{-1}
\end{aligned}
$$

Estimates of $\mathrm{B}_{0}$ and $\Sigma_{\mu}$ can be obtained only through sample estimates of $\Sigma_{t}$. Given that the diagonal elements of $B_{0}$ are all unity, $B_{0}$ contains $\left(\mathrm{n}^{2}-\mathrm{n}\right)$ unknown parameters. $\Sigma_{\mu}$ contains $\mathrm{n}$ unknown values. Thus, the right hand side of equation (7) has a total of $\mathrm{n}^{2}$ unknown values. Since $\Sigma_{t}$ is symmetric, it contains only $\left(\mathrm{n}^{2}+\mathrm{n}\right) / 2$ distinct known elements. In order to identify the $\mathrm{n}^{2}$ unknown structural parameters from the known $\left(\mathrm{n}^{2}+\mathrm{n}\right) / 2$ distinct elements of $\Sigma_{t}$, the minimum requirement is to impose $\left(n^{2}-n\right) / 2$ restrictions on the system. In the structural VAR model, $B_{0}$ can be any structure as long as it satisfies the minimum restriction requirement.

There are several ways of specifying the restrictions to achieve identification of the structural parameters. A simple method is to orthogonalize reduced form errors by Choleski decomposition as originally applied by Sims (1980). This is fairly popular method because it is easy to handle econometrically. This approach to identification requires the assumption that the system of equations follows a recursive scheme. However, this approach should only be used when the recursive ordering implied by this identification is supported by theoretical consideration. The 
alternative and more common approach to identify a structural VAR is to use the restrictions that are implied from a fully specified macroeconomic model. The structural VAR model estimated by Blanchard and Watson (1986), who uses theory to impose short-run restrictions, is an example of this approach. Since the Choleski decomposition is a special case of a more general approach used by Blanchard and Watson and it is easy to handle econometrically, we use this approach to identify the restrictions. The relationship between the reduced form VAR residuals and the structural innovations is given below in equation (8):

$$
\left[\begin{array}{l}
\varepsilon_{f} \\
\varepsilon_{m} \\
\varepsilon_{r} \\
\varepsilon_{e} \\
\varepsilon_{p} \\
\varepsilon_{y}
\end{array}\right]=\left[\begin{array}{l}
\mathrm{f}_{0} \\
m_{0} \\
\mathrm{r}_{0} \\
\mathrm{e}_{0} \\
\mathrm{p}_{0} \\
\mathrm{y}_{0}
\end{array}\right]+\left[\begin{array}{cccccc}
1 & 0 & 0 & 0 & 0 & 0 \\
\mathrm{a}_{21} & 1 & 0 & 0 & 0 & 0 \\
\mathrm{a}_{31} & \mathrm{a}_{32} & 1 & 0 & 0 & 0 \\
\mathrm{a}_{41} & \mathrm{a}_{42} & \mathrm{a}_{43} & 1 & 0 & 0 \\
a_{51} & \mathrm{a}_{52} & \mathrm{a}_{53} & \mathrm{a}_{54} & 1 & 0 \\
a_{61} & \mathrm{a}_{62} & \mathrm{a}_{63} & \mathrm{a}_{64} & \mathrm{a}_{65} & 1
\end{array}\right]\left[\begin{array}{l}
\mu_{f} \\
\mu_{m} \\
\mu_{r} \\
\mu_{e} \\
\mu_{p} \\
\mu_{y}
\end{array}\right]
$$

where $\mathrm{f}_{0}, \mathrm{e}_{0}, \mathrm{r}_{0}, \mathrm{~m}_{0}, \mathrm{p}_{0}$ and $\mathrm{y}_{0}$ are constants and $\mathrm{a}_{\mathrm{ij}}$ represent coefficients. As shown in equation (8), the import price level equation is ordered first because the reduced form residuals in this equation are unlikely to be contemporaneously affected by any other shocks other than their own. This restriction implies that import prices do not respond to contemporaneous changes from other variables but all other variable in the system are contemporaneously affected by change in import prices in a small open economy like Pakistan. The money supply equation is ordered next because it reasonable to assume that monetary shocks have contemporaneous effects on all domestic variables in the system. The nominal interest rate equation is ordered third because in Pakistan, the interest rate is effectively managed by the State Bank of Pakistan at a predetermined level and does not respond to contemporaneous changes in other macro economic variables except import prices as it puts pressure on the country's limited foreign reserves. The nominal effective exchange rate equation is ordered next because import prices and monetary shocks have a contemporaneous effect on the exchange rate. The price level equation is ordered fifth because contemporaneous shocks in all nominal variables in the system are likely to affect the residuals in the price level equation. The output equation is ordered last by assuming that output is contemporaneously affected by all shocks in the system. 
To avoid spurious statistical inferences, the VAR models are usually estimated in first difference form if the data series are non-stationary in the level form. Shocks to the differenced variables will have a temporary effect on the growth rate but a permanent effect on its level. Estimation of a VAR model with stationary variables is consistent regardless whether the time series are cointegrated or not. If, however, the series are integrated of order one, I(1), and cointegrated, then we need to include additional information gained from the long-run relationship to get efficient estimates. This requires the inclusion of a vector of cointegrating residuals in the VAR with differenced variables. This is known as a vector error correction model (VECM).

\section{Data and Estimation Results}

\section{Data}

The key macroeconomic variables are manufacturing output index $\left(\mathrm{Y}_{\mathrm{t}}\right)$, consumer price index $\left(\mathrm{P}_{\mathrm{t}}\right)$, M2 definition of money supply $\left(\mathrm{M}_{\mathrm{t}}\right)$, nominal effective exchange rate $\left(E_{t}\right)$, short-term interest rate measured by call money rates $\left(\mathrm{R}_{t}\right)$ and unit value of imports $\left(\mathrm{E}_{t}\right)$. The unit value of imports index $(2000=100)$ is measured in U.S. dollars by using the bilateral nominal exchange rate of Pakistan rupee and U.S. dollar. The nominal effective exchange rate index $(2000=100)$ is a weighted average of major trading partners and an increase in index means appreciation. The data are quarterly and the sample period for the variables is 1975:12005:4. All variables are in nominal values, except manufacturing output. In addition, all variables are taken from International Financial Statistics (IFS) and measured in logarithmic form. Manufacturing output, consumer price index, unit value of imports and money supply series are seasonally adjusted using X12 program.

\section{Unit root tests}

We first test the hypothesis that a time series contains a unit root and thus follows a random walk process. The implication of this test is to determine whether the VAR model should be estimated in the level or first difference form. To test for unit roots, we use the augmented Dicky-Fuller (ADF) test and and the Philips-Perron test. Test results for unit roots are reported in Table- 2 . 
Table-2: ADF and PP tests for unit roots

\begin{tabular}{|c|c|c|c|c|}
\hline \multirow[t]{2}{*}{ Variable } & \multicolumn{2}{|c|}{ ADF test for a unit root } & \multicolumn{2}{|c|}{ Pp test for a unit root } \\
\hline & Without trend & With trend & Without trend & With trend \\
\hline $\mathrm{F}_{t}$ & -0.80 & -3.20 & -0.70 & -2.19 \\
\hline $\mathrm{E}_{t}$ & -0.03 & -2.53 & -0.07 & -2.53 \\
\hline $\mathrm{R}_{t}$ & -2.78 & -2.94 & $-3.76^{* *}$ & $-4.04^{* *}$ \\
\hline $\mathrm{Y}_{t}$ & 0.18 & -1.19 & -0.34 & -2.02 \\
\hline $\mathrm{P}_{t}$ & -0.88 & -1.34 & -1.14 & -1.30 \\
\hline $\mathrm{M}_{t}$ & -0.65 & -2.60 & -1.40 & -2.93 \\
\hline$\Delta \mathrm{F}_{t}$ & $-5.77^{* *}$ & $-5.75^{* *}$ & $-11.95^{* *}$ & $-11.92 * *$ \\
\hline$\Delta \mathrm{E}_{t}$ & $-10.21^{* *}$ & $-10.41^{* *}$ & $-10.21^{* *}$ & $-10.39 * *$ \\
\hline$\Delta \mathrm{R}_{t}$ & $-5.05 * *$ & $-5.02^{* *}$ & $-15.59 * *$ & $-15.52^{* *}$ \\
\hline$\Delta \mathrm{Y}_{t}$ & $-11.40^{* *}$ & $-11.37^{* *}$ & $-16.60^{* *}$ & $-16.53^{* *}$ \\
\hline$\Delta \mathbf{P}_{t}$ & $-5.08^{* *}$ & $-5.12^{* *}$ & $-9.04 * *$ & $-9.04 * *$ \\
\hline$\Delta \mathrm{M}_{t}$ & $-3.71 * *$ & $-3.56^{*}$ & $-10.76^{* *}$ & $-10.87^{* *}$ \\
\hline \multicolumn{5}{|c|}{ Critical Values for rejecting the null hypothesis of unit root } \\
\hline & ADF test & & PP test & \\
\hline & Without drift & With drift & Without drift & With drift \\
\hline $1 \%$ & -3.49 & -4.04 & -3.48 & -4.03 \\
\hline $5 \%$ & -2.89 & -3.45 & -2.88 & -3.45 \\
\hline $10 \%$ & -2.58 & -3.15 & -2.58 & -3.15 \\
\hline
\end{tabular}

Note: unit root tests are performed for the period 1975:1-2005:4

$$
\begin{array}{ll}
\text { ADF test: } & \Delta \mathrm{X}_{\mathrm{t}}=\phi_{0}+\phi_{1} \mathrm{X}_{\mathrm{t}-1}+\sum_{j=1}^{k} \alpha_{j} \Delta \mathrm{X}_{\mathrm{t}-\mathrm{j}}+\eta_{t} \\
\text { PP test: } & \mathrm{X}_{\mathrm{t}}=\beta_{0}+\beta_{1} \mathrm{X}_{\mathrm{t}-1}+\varepsilon_{t}
\end{array}
$$

where $X_{t}$ represent the natural $\log$ of a time series in the level form. $\Delta$ is the first difference operator. The tabulated values are $t$-statistics to test the null hypothesis of unit root $\left(\varphi_{1}=0\right)$ for ADF test and $\left(B_{1}=0\right)$ for PP test. The appropriate lag length $(\mathrm{k})$ was selected using Akike information criterion with maximum $\operatorname{lags}(\mathrm{k})=8$. *indicates significant at $5 \%$ level. **indicates significant at $1 \%$ level. 
As shown in Table-2, the ADF and PP tests are reported with and without the time trends. Examination of the test results in table 2 shows that the $\mathrm{ADF}$ test fails to reject the null hypothesis of single unit root for all variables. However, the PP test strongly rejects the null hypothesis of single unit root for the interest rate variable. Since the ADF and PP tests provide conflicting results for the interest rate series, we also performed the Kwiatkowski, Phillips, Schmidt, and Shin (KPSS) (1992) test to check for unit roots in the interest rate series. The KPSS test differs from the other unit root tests because it reverses the null (unit root) and the alternative (stationary) hypotheses. The KPSS test strongly rejected the null hypothesis of stationary for interest rate series.

The null hypothesis of two unit roots is rejected by both tests for all variables at the $5 \%$ significance level. Thus, the evidence suggests that first differencing is sufficient for modeling the time series considered in our study.

\section{Tests for cointegration}

Unit root tests reveal that variables included in the VAR model are I(1). Next, we perform Johansen's cointegration test (Johansen, 1991) to see whether these variables are cointegrated. To determine the number of cointegrating vectors, Johansen developed two likelihood ratio statistics: Trace statistics $\left(\lambda_{\text {trace }}\right)$ and maximum eigenvalue statistic $\left(\lambda_{\max }\right)$. The results of cointegration tests are reported in Table-3.

Table-3: Johansen Cointegration tests

\begin{tabular}{cccccccc}
\hline \multicolumn{2}{c}{ Trace test $\left(\lambda_{\text {trace }}\right)$} & \multicolumn{2}{c}{$\mathrm{K}=2$} & \multicolumn{3}{c}{ Maximum eigenvalue test } & $\left(\lambda_{\max }\right) \mathrm{k}=2$ \\
\hline $\mathrm{H} 0$ & $\mathrm{HA}$ & $\left(\lambda_{\text {trace }}\right)$ & $\begin{array}{c}\text { Critical } \\
\text { Values } 5 \%\end{array}$ & $\mathrm{H} 0$ & $\mathrm{HA}$ & $\left(\lambda_{\max }\right)$ & $\begin{array}{c}\text { Critical } \\
\text { Values } 5 \%\end{array}$ \\
\hline $\mathrm{r} \leq 0$ & $\mathrm{r}>0$ & 108.01 & 95.75 & $\mathrm{r}=0$ & $\mathrm{r}=0$ & 44.45 & 40.07 \\
$\mathrm{r} \leq 1$ & $\mathrm{r}>1$ & 63.56 & 69.82 & $\mathrm{r}=1$ & $\mathrm{r}=1$ & 21.30 & 33.88 \\
$\mathrm{r} \leq 2$ & $\mathrm{r}>2$ & 42.26 & 47.86 & $\mathrm{r}=2$ & $\mathrm{r}=2$ & 19.23 & 27.58 \\
$\mathrm{r} \leq 3$ & $\mathrm{r}>3$ & 23.03 & 29.80 & $\mathrm{r}=3$ & $\mathrm{r}=3$ & 15.74 & 21.13 \\
$\mathrm{r} \leq 4$ & $\mathrm{r}>4$ & 7.28 & 15.49 & $\mathrm{r}=4$ & $\mathrm{r}=4$ & 6.98 & 14.26 \\
$\mathrm{r} \leq 5$ & $\mathrm{r}>5$ & 0.30 & 3.84 & $\mathrm{r}=5$ & $\mathrm{r}=5$ & 0.30 & 3.84 \\
\hline
\end{tabular}

Note: $\mathrm{r}$ represents number of cointegrating vectors and $\mathrm{k}$ represents the number of lags in the unrestricted VAR model. 
Cointegration tests are performed under the assumption of a linear trend in the data, and an intercept but no trend in the cointegrating equation. With maximum lags set to eight, the lag length was selected using different lag selection criteria in the unrestricted VAR model. Sequential modified likelyhood ratio test, final prediction error criterion and Akaike's information criterion all selected two lags in the unrestricted VAR model. As shown in table 3, the null hypothesis that the variables in the VAR are not cointegrated $(\mathrm{r}=0)$ is rejected at the $5 \%$ significance level under both tests. However, the null hypothesis of one cointegrating relation among the variables $(r=1)$ can not be rejected under either test.

\section{Reduced Form Estimation Results}

Having established that all variables in the model are $\mathrm{I}(1)$ and cointegrated, a VECM with one cointegrating relation and two lags in each equation was estimated. The VECM allows the long-run behavior of the endogenous variables to converge to their long-run equilibrium relationship while allowing a wide range of short-run dynamics. To save space, only the estimated coefficients of the cointegrating equation and other statistics in VECM are reported in table 4 below.

Table-4: Summary of VECM estimation

\begin{tabular}{lcccccc}
\hline & $\begin{array}{c}\text { Import } \\
\text { Prices } \\
(\mathbf{F})\end{array}$ & $\begin{array}{c}\text { Money } \\
\text { Supply } \\
(\mathbf{M})\end{array}$ & $\begin{array}{c}\text { Interest } \\
\text { Rate } \\
(\mathbf{R})\end{array}$ & $\begin{array}{c}\text { Exchange } \\
\text { Rate } \\
(\mathbf{E})\end{array}$ & $\begin{array}{c}\text { Price } \\
\text { level } \\
(\mathbf{P})\end{array}$ & $\begin{array}{c}\text { Output } \\
(\mathbf{Y})\end{array}$ \\
\hline Error Correction & -0.046 & 0.007 & -0.016 & -0.019 & 0.001 & -0.039 \\
Term & $(4.27)$ & $(1.78)$ & $(0.32)$ & $(1.43)$ & $(0.51)$ & $(4.35)$ \\
& 0.10 & 0.14 & 0.11 & -0.02 & 0.27 & 0.31 \\
Adjusted R ${ }^{2}$ & 0.05 & 0.02 & 0.25 & 0.06 & 0.01 & 0.04 \\
Term & & & & & &
\end{tabular}

Note: The VECM was estimated using two lags in each equation. Absolute $t$-values are given in parentheses. SEE stands for the standard error of the equation.

Examination of Table-4 shows that the long-run relationship is established at the $1 \%$ significance level for output and import prices and at the $10 \%$ level for money supply within two quarters. However, for other variables convergence to their equilibrium path takes longer than two quarters. 


\section{Granger Causality Tests}

The VECM approach not only enables us to determine the direction of causality among the variables, but it also allows us to distinguish between the two types of Granger causality: short-run and long-run causality. The long-run causality from independent variables to the dependent variable is evaluated by testing the null hypothesis that the coefficient $(\lambda)$ of the error correction term $\left(\mathrm{EC}_{\mathrm{t}-1}\right)$ is zero. Short-run causality from an independent variable to the dependent variable is evaluated by testing the null hypothesis that each coefficient $\left(\beta_{\mathrm{i}}\right)$ on the independent variable is zero. By rejecting either of the two hypotheses, we conclude that independent variables Granger cause the dependent variable. Based on our VECM, Granger causality tests are reported below in Table- 5 .

Table-5: Results of Granger causality tests

\begin{tabular}{|c|c|c|c|c|c|c|c|}
\hline & \multicolumn{7}{|c|}{ Independent variables } \\
\hline & $\mathrm{EC}_{\mathrm{t}-1}$ & $\Delta \mathrm{F}_{\mathrm{t}}$ & $\Delta \mathrm{M}_{\mathrm{t}}$ & $\Delta \mathrm{R}_{\mathrm{t}}$ & $\Delta \mathrm{E}_{\mathrm{t}}$ & $\Delta \mathrm{P}_{\mathrm{t}}$ & $\Delta Y_{t}$ \\
\hline & $\mathrm{t}(=0)$ & & & & $3 \mathbf{i}=0)$ & & \\
\hline \multicolumn{8}{|c|}{ Dependent variable } \\
\hline$\Delta \mathrm{F}_{i}$ & $-4.27^{* * *}$ & --- & 1.69 & 0.64 & 0.14 & $2.32^{*}$ & 0.56 \\
\hline$\Delta \mathrm{M}_{i}$ & $1.78^{*}$ & 1.14 & $-\cdots$ & 0.87 & 0.44 & $2.35^{*}$ & 2.01 \\
\hline$\Delta \mathrm{R}_{i}$ & -0.32 & 0.08 & 1.65 & --- & 0.50 & 2.12 & $2.73 *$ \\
\hline$\Delta \mathrm{E}_{i}$ & -1.43 & 0.26 & 0.28 & 0.67 & --- & 2.19 & 0.90 \\
\hline$\Delta \mathrm{P}_{i}$ & 0.51 & $3.32 * *$ & $4.46^{* *}$ & 0.35 & $7.80 * * *$ & --- & 0.70 \\
\hline$\Delta \mathrm{Y}_{i}$ & $-4.35^{* * *}$ & $2.67^{*}$ & 0.62 & 0.74 & 0.10 & 1.70 & --- \\
\hline
\end{tabular}

Note: $t(\lambda=0)$ and $F(\beta i=0)$ are the $t$-statistic for testing the null hypothesis that the coefficient of error correction term is zero and the standard F-statistic for testing the null hypothesis that all coefficients on the independent variables are zeroes, ${ }^{* * *}, * *, *$ indicate significance at the $1 \%, 5 \%$ and $10 \%$, levels respectively.

Results presented in Table-5 indicate the presence of long-run causality from all the variables to output growth. However, there is only short-run causality from imported inflation, money growth and exchange rate to domestic inflation. In short, we can say that exchange rate does Granger cause inflation and output growth. 


\section{Variance decomposition results}

Table- 6 presents the variance decomposition of the variables in the model. The table shows the percentage of the forecast error variance for each variable that is attributable to its own shocks and to shocks in the other variables in the system. The most important conclusions from the variance decomposition are as follows. First, for all variables except the output (LY), the predominant source of variation are own shocks. Second, over the medium-term (first 6 quarters), about 76 percent of variance in output forecast errors is explained by own shocks and only 24 percent by shocks in all other variables in the system. Over the long-term ( 24 quarters), the situation is reversed where own shocks account only about 25 percent while shocks in other variables explain 75 percent of the forecast error variance of output. Over the longer period, the domestic price level is the predominant source of variation in output. Domestic price shocks explain about $38 \%$ of the forecast error variance of output. The effect of interest rates, import prices and money shocks to output is about 19\%, 10\% and $7 \%$ respectively. However, surprisingly the impact of nominal effective exchange rate on output is quite unimportant. Exchange rate shocks account for only 0.5 to $1.5 \%$ of the forecast error variance of output. Third, over the shortterm (two quarters), import price shocks are relatively more important in explaining variation in the price level than shocks in other variables. Import price shocks interpret $6.27 \%$ while shocks in all other variables combined explain only $6.23 \%$ of the forecast error variance of price level over a time span of two quarters. However, in the long-run, money and exchange rate shocks become more important to explain variation of price level. The longterm effect of money, the exchange rate, and import price shocks on price level variation is about $18 \%, 9 \%$ and $6 \%$ respectively. The effect of output shocks on the price level is statistically insignificant at all time horizons. Fourth, almost all of the variation in the exchange rate and interest rates is explained by own shocks and money shocks, while the impact of other variables on the exchange rate and interest rates is insignificant. Money shocks explain $13.4 \%$ and $11.9 \%$ of the forecast error variance of the exchange rate and interest rates, respectively. We can conclude that effects of monetary policy are transmitted through both the exchange rate channe1 and the interest rate channel. Fifth, the variance of money supply is explained primarily by its own shocks and by output shocks. In summary, output and the price level do not explain any variation in the exchange rate but exchange rate shocks do explain variation in the price level.

Table-6: Variance decomposition from the Vector Error Correction Model 


\begin{tabular}{cccccccc}
\hline \multicolumn{7}{l}{ Variance Decomposition of LFP: } \\
\hline Period & S.E. & LFP & LM2 & LR & LNEER & LP & LY \\
\hline 2.00 & 0.07 & 96.46 & 0.12 & 0.00 & 0.00 & 1.03 & 2.40 \\
4.00 & 0.09 & 91.15 & 0.42 & 0.41 & 0.67 & 1.80 & 5.55 \\
6.00 & 0.11 & 84.91 & 2.12 & 1.84 & 1.38 & 1.26 & 8.50 \\
8.00 & 0.13 & 78.28 & 4.47 & 4.01 & 1.47 & 1.14 & 10.62 \\
10.00 & 0.15 & 72.04 & 6.58 & 6.28 & 1.35 & 1.61 & 12.13 \\
12.00 & 0.17 & 66.73 & 8.17 & 8.30 & 1.17 & 2.42 & 13.21 \\
14.00 & 0.19 & 62.44 & 9.27 & 9.99 & 1.01 & 3.30 & 13.98 \\
16.00 & 0.20 & 59.01 & 10.04 & 11.37 & 0.87 & 4.14 & 14.56 \\
18.00 & 0.22 & 56.26 & 10.58 & 12.49 & 0.77 & 4.89 & 15.01 \\
20.00 & 0.23 & 54.03 & 10.98 & 13.40 & 0.68 & 5.53 & 15.37 \\
22.00 & 0.24 & 52.19 & 11.29 & 14.16 & 0.61 & 6.08 & 15.67 \\
24.00 & 0.26 & 50.66 & 11.53 & 14.79 & 0.55 & 6.55 & 15.91 \\
\hline & & Variance Decomposition of LM2: & & \\
\hline Period & S.E. & LFP & LM2 & LR & LNEER & LP & LY \\
\hline 2.00 & 0.03 & 1.42 & 96.77 & 0.36 & 0.30 & 1.15 & 0.01 \\
4.00 & 0.05 & 0.81 & 96.42 & 0.49 & 0.37 & 1.18 & 0.73 \\
6.00 & 0.06 & 0.76 & 95.93 & 0.36 & 0.52 & 1.03 & 1.40 \\
8.00 & 0.07 & 0.85 & 95.41 & 0.27 & 0.62 & 0.80 & 2.06 \\
10.00 & 0.08 & 1.00 & 94.75 & 0.28 & 0.65 & 0.63 & 2.69 \\
12.00 & 0.09 & 1.19 & 93.95 & 0.39 & 0.64 & 0.57 & 3.26 \\
14.00 & 0.10 & 1.38 & 93.12 & 0.56 & 0.60 & 0.60 & 3.75 \\
16.00 & 0.10 & 1.55 & 92.30 & 0.74 & 0.55 & 0.69 & 4.16 \\
18.00 & 0.11 & 1.71 & 91.55 & 0.92 & 0.51 & 0.81 & 4.50 \\
20.00 & 0.12 & 1.85 & 90.88 & 1.08 & 0.47 & 0.94 & 4.78 \\
22.00 & 0.12 & 1.97 & 90.29 & 1.23 & 0.44 & 1.06 & 5.01 \\
24.00 & 0.13 & 2.07 & 89.77 & 1.36 & 0.41 & 1.17 & 5.21 \\
\hline & & Variance Decomposition of LR: & & \\
\hline & & & & & & & \\
\hline
\end{tabular}




\begin{tabular}{cccccccc}
\hline Period & S.E. & LFP & LM2 & LR & LNEER & LP & LY \\
\hline 2.00 & 0.30 & 0.05 & 1.31 & 95.27 & 0.69 & 0.29 & 2.39 \\
4.00 & 0.39 & 0.17 & 2.15 & 93.19 & 0.51 & 2.20 & 1.78 \\
6.00 & 0.47 & 0.24 & 3.82 & 90.96 & 0.41 & 2.98 & 1.58 \\
8.00 & 0.54 & 0.29 & 5.66 & 88.95 & 0.38 & 3.32 & 1.41 \\
10.00 & 0.59 & 0.30 & 7.25 & 87.40 & 0.35 & 3.41 & 1.29 \\
12.00 & 0.65 & 0.30 & 8.51 & 86.24 & 0.32 & 3.41 & 1.22 \\
14.00 & 0.69 & 0.30 & 9.46 & 85.38 & 0.30 & 3.38 & 1.17 \\
16.00 & 0.74 & 0.30 & 10.19 & 84.74 & 0.28 & 3.36 & 1.13 \\
18.00 & 0.78 & 0.30 & 10.76 & 84.24 & 0.27 & 3.33 & 1.10 \\
20.00 & 0.82 & 0.30 & 11.21 & 83.85 & 0.25 & 3.31 & 1.07 \\
22.00 & 0.86 & 0.30 & 11.58 & 83.52 & 0.24 & 3.30 & 1.05 \\
24.00 & 0.90 & 0.30 & 11.90 & 83.25 & 0.23 & 3.28 & 1.04 \\
\hline
\end{tabular}

Variance Decomposition of LNEER:

\begin{tabular}{cccccccc}
\hline Period & S.E. & LFP & LM2 & LR & LNEER & LP & LY \\
\hline 2.00 & 0.10 & 0.87 & 2.05 & 0.32 & 95.86 & 0.89 & 0.01 \\
4.00 & 0.13 & 0.69 & 4.35 & 0.22 & 93.54 & 0.56 & 0.62 \\
6.00 & 0.17 & 0.57 & 6.76 & 0.27 & 90.99 & 0.64 & 0.77 \\
8.00 & 0.19 & 0.49 & 8.65 & 0.42 & 88.66 & 0.88 & 0.90 \\
10.00 & 0.22 & 0.42 & 10.03 & 0.58 & 86.82 & 1.16 & 0.99 \\
12.00 & 0.24 & 0.37 & 11.01 & 0.73 & 85.41 & 1.42 & 1.06 \\
14.00 & 0.26 & 0.33 & 11.70 & 0.85 & 84.35 & 1.66 & 1.11 \\
16.00 & 0.28 & 0.30 & 12.22 & 0.94 & 83.53 & 1.85 & 1.15 \\
18.00 & 0.29 & 0.28 & 12.61 & 1.02 & 82.89 & 2.01 & 1.19 \\
20.00 & 0.31 & 0.26 & 12.92 & 1.09 & 82.37 & 2.15 & 1.22 \\
22.00 & 0.32 & 0.24 & 13.17 & 1.14 & 81.94 & 2.26 & 1.24 \\
24.00 & 0.34 & 0.23 & 13.38 & 1.19 & 81.58 & 2.36 & 1.26 \\
\hline
\end{tabular}




\begin{tabular}{cccccccc}
\hline \multicolumn{7}{c}{ Variance Decomposition of LP: } \\
\hline Period & S.E. & LFP & LM2 & LR & LNEER & LP & LY \\
\hline 2.00 & 0.02 & 6.27 & 3.12 & 2.78 & 0.22 & 87.50 & 0.11 \\
4.00 & 0.03 & 6.47 & 7.41 & 3.85 & 5.42 & 76.82 & 0.04 \\
6.00 & 0.04 & 6.41 & 11.14 & 3.75 & 7.45 & 71.22 & 0.02 \\
8.00 & 0.05 & 6.35 & 13.81 & 3.66 & 8.33 & 67.84 & 0.02 \\
10.00 & 0.05 & 6.31 & 15.52 & 3.62 & 8.75 & 65.77 & 0.03 \\
12.00 & 0.06 & 6.30 & 16.55 & 3.65 & 8.96 & 64.50 & 0.04 \\
14.00 & 0.07 & 6.30 & 17.14 & 3.70 & 9.10 & 63.71 & 0.05 \\
16.00 & 0.07 & 6.31 & 17.48 & 3.77 & 9.19 & 63.18 & 0.07 \\
18.00 & 0.08 & 6.32 & 17.68 & 3.84 & 9.25 & 62.83 & 0.08 \\
20.00 & 0.09 & 6.33 & 17.80 & 3.91 & 9.31 & 62.57 & 0.09 \\
22.00 & 0.09 & 6.34 & 17.87 & 3.97 & 9.35 & 62.37 & 0.10 \\
24.00 & 0.10 & 6.35 & 17.92 & 4.02 & 9.39 & 62.22 & 0.11 \\
\hline & & Variance Decomposition of LY: & & \\
\hline Period & S.E. & LFP & LM2 & LR & LNEER & LP & LY \\
\hline 2.00 & 0.05 & 6.23 & 0.03 & 0.20 & 0.46 & 4.08 & 89.01 \\
4.00 & 0.06 & 5.78 & 0.44 & 1.32 & 0.55 & 6.13 & 85.77 \\
6.00 & 0.06 & 6.96 & 1.72 & 3.96 & 0.43 & 11.11 & 75.82 \\
8.00 & 0.07 & 7.91 & 3.35 & 7.29 & 0.42 & 17.02 & 64.00 \\
10.00 & 0.08 & 8.49 & 4.69 & 10.29 & 0.53 & 22.31 & 53.70 \\
12.00 & 0.10 & 8.90 & 5.56 & 12.63 & 0.69 & 26.56 & 45.66 \\
14.00 & 0.11 & 9.19 & 6.08 & 14.38 & 0.87 & 29.83 & 39.65 \\
16.00 & 0.12 & 9.41 & 6.38 & 15.69 & 1.03 & 32.33 & 35.16 \\
18.00 & 0.13 & 9.56 & 6.56 & 16.68 & 1.18 & 34.26 & 31.75 \\
20.00 & 0.13 & 9.69 & 6.68 & 17.45 & 1.30 & 35.78 & 29.10 \\
24.00 & 0.14 & 9.78 & 6.75 & 18.07 & 1.40 & 36.99 & 27.01 \\
\hline & 0.15 & 9.86 & 6.80 & 18.56 & 1.49 & 37.97 & 25.31 \\
\hline
\end{tabular}




\section{Impulse Response Functions Analysis}

Having shown the dynamic effects of variance decompositions, we analyze the impulse responses. The variance decompositions do not show the direction of the dynamic effects of the shocks on the variables in the system but the impulse responses do. The impulse response function (IRF) describes the impact of an exogenous shock in one variable on the other variables of the system. A unit (one standard deviation) increase in the $i^{\text {th }}$ variable innovation (residual) is introduced at date $t$ and then it is returned to zero thereafter. In general the path followed by the variable $\mathrm{X}_{\mathrm{i}, \mathrm{t}}$ in response to a one time change in $\mathrm{X}_{\mathrm{i}, \mathrm{t}}$, holding the other variables constant at all times $t$, is called the IRF. The traditional impulse response method based on Cholesky decomposition has been criticized because results are subject to the orthogonality assumption. If the residuals of two (or more) equations contained in the VAR system are contemporaneously correlated, then the impulse responses are not robust to the ordering of the variables. In fact, the impulse responses may display significantly different patterns Lutkenpoh1 (1991). Recently, Pesaran and Shin (1998) have developed a method called the generalized impulse response function (GIRF) which does not impose the orthogonality restriction and thus impulse responses are not sensitive to the ordering of the variables in the VAR and provide more robust results. In this paper we report results both from traditional IRF and generalized IRF. Each figure shows the response of a particular variable to a one time shock in each of the variables included in the VEC model. It should be noted that a one time shock to the first differenced variable is a permanent shock to the level of that variable.

Figure 2 contains the impulse-response functions for output (LY). Examination of the graph shows that the impulse responses meet a priori expectations in terms of the direction of impact. A positive shock to import prices has a significant contractionary effect on the output. The effect of a unit shock to import prices on output occurs immediately and stabilizes after 15 quarters with output decreasing by approximately one percent of its baseline level. The effect of a unit shock to money supply on output occurs after approximately the third quarter, reaching its peak after 12 quarters. Thereafter the cumulative effects of money supply stabilize with output increasing by approximately one percent of its baseline level. Positive interest rate shocks have permanent and negative effects on output. Positive exchange rate shocks (appreciation) lead to an immediate and long lasting decrease in output. The impact of the exchange rate appreciation is rather immediate and long lasting. A unit shock to the exchange rate (appreciation) causes output to decrease approximately 0.5 percent from its base level. Positive price level shocks have a very strong negative effect on output. A 
one unit shock in the price level leads to a $1 \%$ decrease in output by the second quarter and then by more than $2 \%$ over a longer time span.

Figure 2

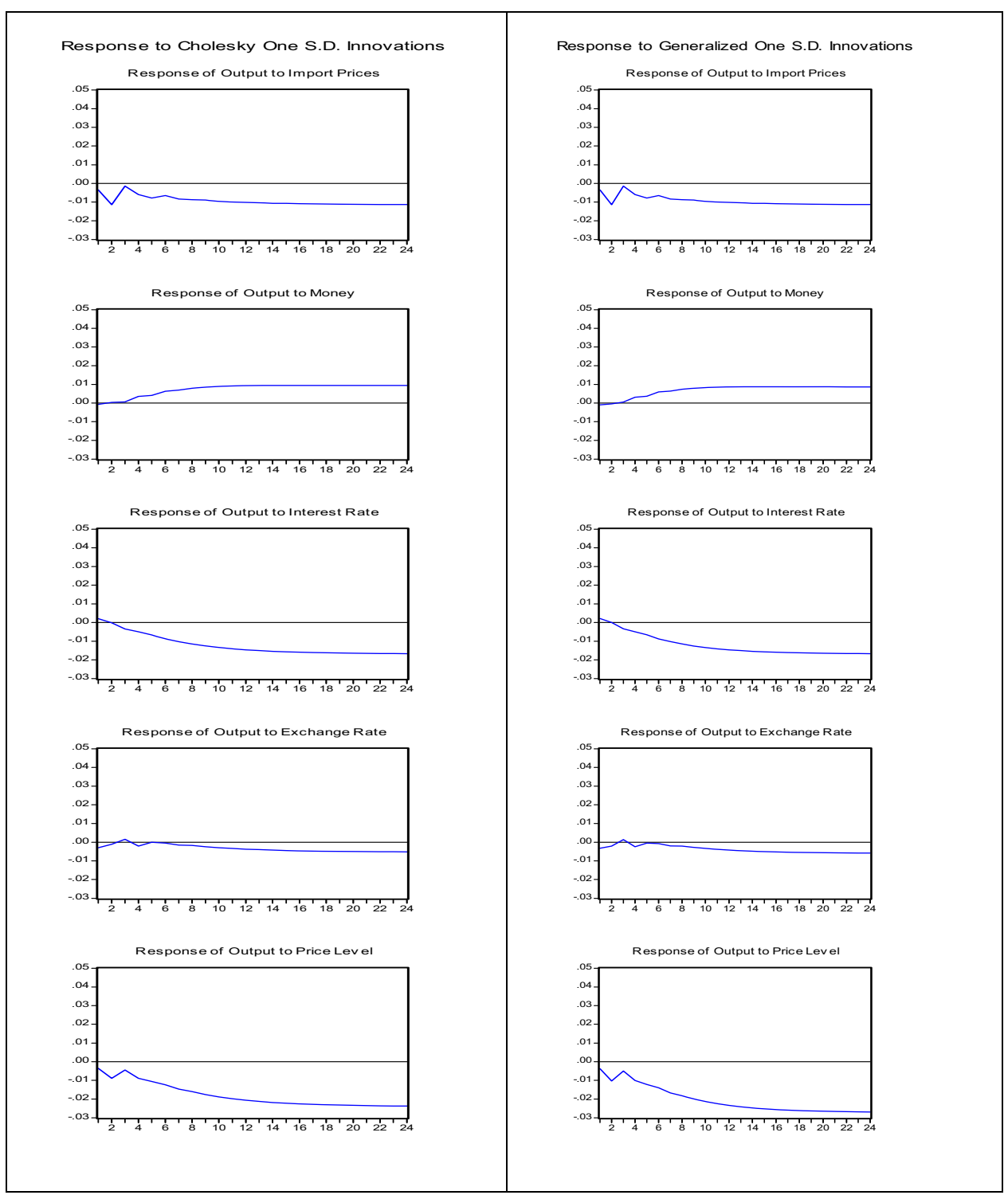

Figure 3 contains the impulse-response functions for the price level (LP). An examination of figure 3 shows that positive shocks in import prices, money supply, the interest rate and exchange rate (appreciation) all have a significant positive and lasting effect on the price level. The effect of output shocks on the price level is marginally negative in the shorter period but 
unclear over the longer period as it is slightly positive in Cholesky innovation where as negative in generalized innovations. Over a period of two quarters, the effect of money supply on the price level is stronger than the effect of exchange rate appreciation. However over a longer period, the effect of an exchange rate appreciation on the price level is almost as strong as the effect of money supply.

Figure 3

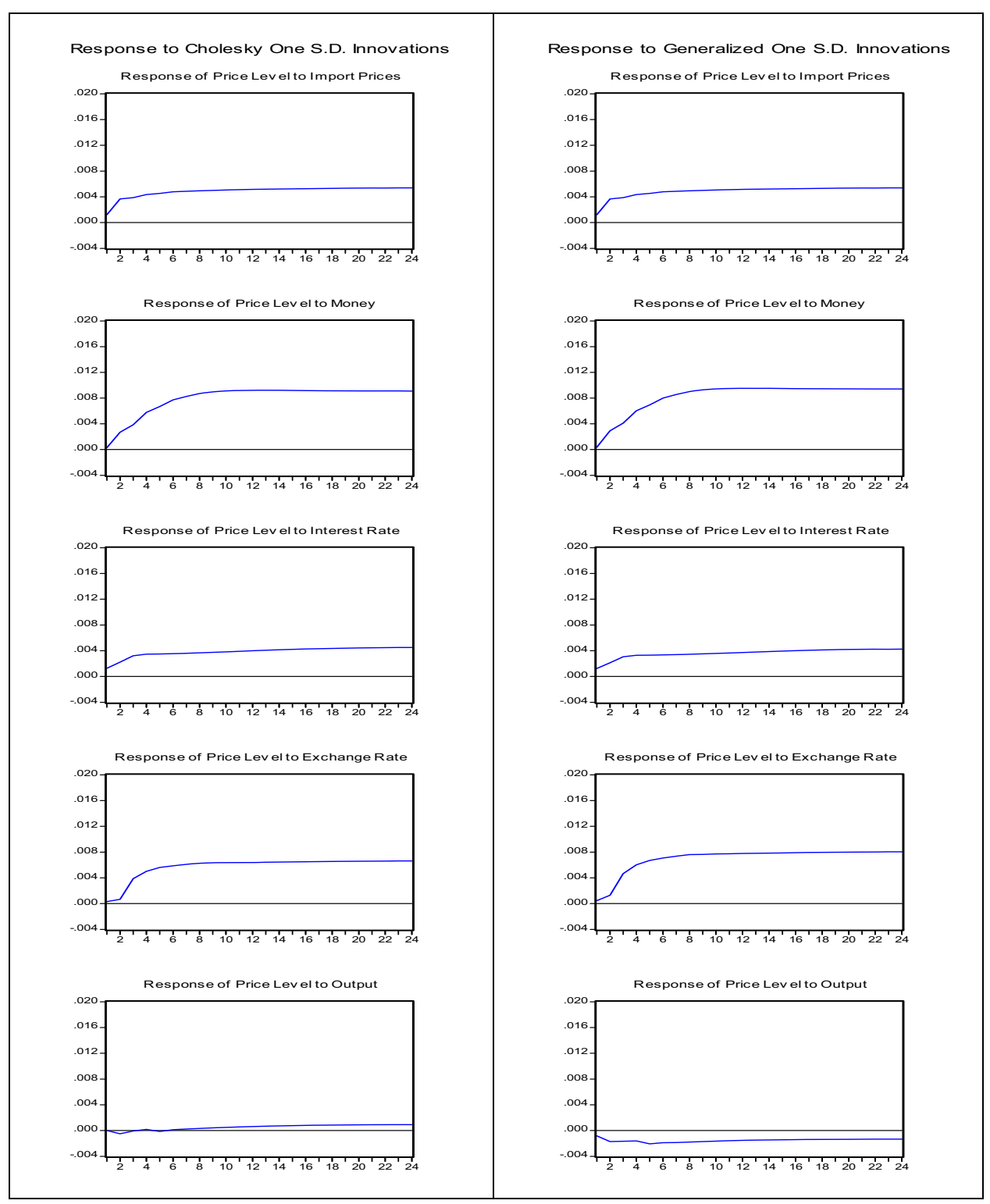


The effect of a unit shock to money supply on the price level occurs quickly and reaches its peak within 10 quarters. The cumulative effects of money supply stabilize with the price level, increasing it by approximately one percent of its baseline level. The effect of a unit shock to exchange rate (appreciation) on the price level is rather slow for the first two quarters and then accelerates quickly and reaches its peak within 10 quarters. The cumulative effects of the exchange rate stabilize with the price level, increasing it by approximately 0.8 percent of its baseline level. The positive effect of the interest rate on the price level confirms the hypothesis that higher interest rates in the developing countries increase the cost of working capital (VanWijnbergen, 1986) and thus causes a leftward shift in the aggregate supply curve.

In summary, a devaluation (negative exchange rate shocks) has a positive effect on output and a negative effect on the price level. The negative effect of a devaluation on the price level fits quite well with the competitive devaluations or "beggar thy neighbor" policies followed by Pakistan and other developing countries exporting similar products and desperately attempting to increase their market share in a world of shrinking markets. Thus, the evidence presented in this paper does not support the contractionary devaluation hypothesis.

\section{Conclusion}

The traditional view was that devaluations are expansionary and that led Pakistan, like many other developing countries, to resort to large devaluations in hope to reap economic benefits. During the fixed exchange rate period (1971-81), the Pak rupee was devalued from 4.79 to 9.90 per US dollar. During the managed float period (1982-1999) the rupee was devalued from 9.90 to 51.78 per US dollar. During the flexible exchange rate period (2000-2006) the rupee has depreciated from 51.78 to 60.60 per US dollar. In recent years, the proposition that devaluations are expansionary has faced a serious threat from new structuralists who claim that devaluations are contractionary. A number of empirical studies have supported the contractionary devaluation hypothesis using pooled time series data from a large number of heterogeneous countries. Since the effects of devaluation on output and price level may not be uniform across all developing countries, it is desirable to conduct country specific studies.

This study has analyzed the effects of exchange rate on output and the price level using a VEC model for the Pakistan economy over the period 1975:1-2005:4. Examination of variance decomposition and impulse responses from a VEC model has revealed a number of important findings. 
First, devaluation has a positive effect on output but a negative effect on the price level. Thus, evidence presented in this paper does not support the contractionary devaluation hypothesis. Second, expansionary monetary policy has a (significant) positive effect on both output and the price level. Third, an increase in import prices has a negative effect on output but a positive effect on the price level. Fourth, an increase in the interest rate has a negative effect on output but a positive effect on the price level. This confirms the structuralists' hypothesis that an increase in the interest rate increases the working cost of capital and thus represents an adverse supply shock rather than adverse demand shock.

In conclusion, these findings imply that policy makers in Pakistan should be very careful when considering a revaluation of the currency or using policy tools under their control in such a way as to achieve appreciation. Similarly, we can say that it is recommended for the authorities to implement a flexible exchange rate system because an overvalued currency is not only inflationary but also hinders economic growth. 


\section{References}

Bahmani-Oskooee, M., 1998, Are devaluations contractionary in LDCs?, Journal of Economic Development, 23, 131-144.

Bahmani-Oskooee, M. Chomsisengphet, S. and Kandil, M., 2002, Are devaluations contractionary in Asia?, Journal of Post Keynesian Economics, 25, 69-81.

Bahmani-Oskooee, M. and Miteza, I., 2006, Are devaluations contractionary? Evidence from Panel Cointegration, Econom.ic Issues, 11, 49-64.

Bahmani-Oskooee, M. and Rhee, H-J., 1997, Response of domestic production to depreciation in Korea: An application of Johansen's cointegration methodology, International Economic Journal, 11, 103-112.

Bruno, M., 1979, Stabilization and stagfiation in a semi-industrialized economy in Dornbusch, R. and Frenke1, J. A. (eds) International Economic Policy. Theory and Evidence, Baltimore.

Cooper, R. N., 1971a, Currency Devaluation in Developing Countries, Essays in International Finance, no. 86.

Cooper, R. N., 1971b, Devaluation and aggregate demand in aid receiving countries in Bhagwati J. N. et al (eds) Trade Balance of Payments and Growth, Amsterdam and New York: North-Holland.

Diaz-Alejandro, C. F., 1963, A Note on the Impact of Devaluation and the Redestributive Effects, Journal of Political Economy, 71, pp.577-80.

Diaz-Alejendro, C. F., 1965, Exchange Rate Devaluation in a SemiIndustrialized Economy: The Experience of Argentina 1955-61, Cambridge, MA., MIT Press.

De Silva, D. and Zhu, Z., 2004, Sri Lanka's Experiment with Devaluation: VAR and ECM Analysis of the Exchange Rate Effects on Trade Balance and GDP, International Trade Journal, Vol. 18, No. 4, pp. 269-301.

Domaç, I., 1997, Are Devaluations Contractionary? Evidence from Turkey, Journal of Economic Development, Volume 22, Number 2, December 1997, pp. 145-163 
Donovan, D., 1982, Macroeconomic Performance and Adjustment under Fund Supported Programs: The Experience of the Seventies, IMF Staff Papers, Vol 29, 171-203.

Dornbusch, R., 1988, Open Economy Macroeconomics, 2nd edition, New York: Basic Books.

Edwards, S., 1986, Are Devaluations Contractionary?, The Review of Economics and Statistics 68, 501-508.

Edwards, S., 1989, Exchange Controls, Devaluations, and the Real Exchange Rates: The Latin American Experience, Economic Development and Cultural Change, Vo1. 37, 457-494.

Gylfason, T., 1987, Credit Policy and Economic Activities in Developing Countries with IMF Stabilization Programs, Princeton Studies in International Finance, No. 60.

Gylfason, T. and Risager O., 1984, Does devaluation improve the current account?, European Economic Review, 25, 37-64.

Gylfason, T. and Schmid, 1983, Does devaluation cause stagflation?, The Canadian Joumai of Economics, 25, 37-64.

Gylfason, T. and Radetzki, M., 1991, Does devaluation make sense in the least developed countries?, Economic Development and Cultural Change, 40, 1-25.

Hasan, M.A. and Khan, A. H., 1994, Impact of Devaluation on Pakistan's External Trade: An Econometric Approach. Pakistan Development Review (33:4) pp 1205-1215, Winter 1994, Part II.

Hanson, J. A., 1983, Contractionary devaluation, substitution in production and consumption and the role of the labour market, Joumai of International Economics, 14, 179-189.

Kamin, S. B., 1988, Devaluation, External Balance, and the Macroeconomic Performance: A Look at the Numbers, Princeton Studies in International Finance, No. 62.

Khan, M. S., 1988, The Macroeconomic Effects of Fund Supported Adjustment Program: An Empirical Assessment, IMF Working Paper, $\mathrm{WP} / 88 / 113$. 
Khan, R. and Aftab, S., 1995, Devaluation and Balance of Trade in Pakistan. Paper presented at the Eleventh Annual General Meeting and Conference of Pakistan Society of Development Economists, April, 1821, Islamabad.

Killick, T., Malik, M. and Manue1, M., 1992, What Can We Know About the Effects of IMF Programmes?, The World Economy 15: 575-597.

Knight, J. B., 1976, Devaluation and Income Distribution in Less Developed Economies, Oxford Economic Papers, 28, 208-227.

Krugman, P. and Taylor, L., 1978, Contractionary Effects of Devaluation, Journal of International Economics. v. 8, p. 445-456.

Kwiatkowski, D., Phillips, P.C.B., Schmidt, P., Shin, Y., 1992, Testing the null hypothesis of stationarity against the alternative of a unit root, Journal of Econometrics 54, 159-178.

Lutkenpoh1, H., 1991, Introduction to Multiple Time Series Analysis, Springer-Verlag, Berlin, 1991.

Morley, S., 1992, On the Effects of Devaluation During Stabilization Programs in LDCs, Review of Economics and Statistics, LXXIV, 21-27.

Pesaran, M. H. and Shin, Y., 1998, Generalized impulse response analysis in linear multivariate models, Economics Letters, 58, 17-29.

Roca, S. and Priale, R., 1987, Devaluation, Inflationary Expectations and Stabilization in Peru, Journal of Economic Studies, Vo1. 14, 5-33.

Sheehey, E. J., 1986, Unanticipated infiation, devaluation and output in Latin America, World Development, 14, 665-671.

Solimano, A., 1986, Contractionary Devaluation in the Southern Cone: The Case of Chile, Journal of Development Economics, 23, 135-151.

Upadhyaya, K. P., 1999, Currency Devaluation, Aggregate Output, and the Long Run: An Empirical Study, Economics Letters, 64, 197-202.

Van Wijnbergen, S. V., 1986, Exchange Rate Management and Stabilization Policies in Developing Countries, Journal of Development Economics, 23, 227-247. 
